feminine adjective by Aphrahat. The phrase مبر of occurs, moreover, in the Old Syriac Gospels (Syriin) in Mark xiii 11 ; Luke ii 25 , 26 ; John $\mathbf{x x 2 2}$; and Prof. Burkutt cites it in Evangelion i 172 from a sixth-century MS of the Acts of Thomas. But the phrase Lo; م. with the masculine adjective, is almost certainly later than the phrase tapog pos which prevails not only in the Peshitta, but also in the Old Syriac Gospels, in Aphrahat and in Addai ${ }^{~}$.

The later history of the text of the Jacobite Form of the Psalter Creed is illustrated by the various readings given above. There was a tendency to make it more definite by alterations and additions. The Greek word ov $\sigma^{\prime} \boldsymbol{i} \alpha$ is introduced in five MSS in a transliterated form to help to translate o $\mu o o v \sigma c o v$. Two MSS introduce, and one defends, the epithet Mother of God', the very watchword against the Nestorians. Three MSS at the end of the description of the oikovouia of the Incarnation boldly substitute the note as he willed for the time-honoured appeal according as it is written, the former being a characteristic Monophysite watchword ${ }^{3}$. Three MSS assimilate the language of the Jacobite Creed to the 'enlarged' Nicene by reading م. م. مoj, the Holy Spirit (with the adjective in the masculine) for 1apol the Spirit of Holiness (a feminine, though often treated as masculine in the Peshitta) ${ }^{4}$. Lastly, four of the earlier MSS add (in the definite form) St Paul's epithet v 27), to the description of the Church. The Jacobite, unlike the Nestorian, dealt somewhat freely with the text of his Creed.

W. EMERY BARNes.

\title{
THE MAGNIFICAT IN NICETA OF REMESIANA AND CYRIL OF JERUSALEM.
}

NicETa witnesses to the traditions of the old Latin Church of the Danube when in his treatise de Psalmodiae Bono he ascribes the Magnificat to Elisabeth: ' Nec Elisabeth, diu sterllis, edito de repromissione filo Deum de ipsa anima magnificare cessavit' c. 9, 'Cum Elisabeth Dominum anima nostra magnificat' $c$. Ir. Mr Burkitt has stated that 'the reading is already well known to textual critics, being found in $a, b, l$, and also in Irenaeus 235'". The reading in the Codex Vercellensis,

1 The only form besides hooj used absolutely which I have noticed in Ephraim

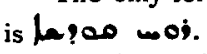

Also in the Creed of the Jacobite Liturgy published by Brightman (p. 82).

- The Creed of Severus of Antioch (Brit. Mus. Add. I 7109 , fol. 147 a) confesses,

'He died for sinners according as He willed and because He willed'.

- Feminine, Acts $\times 44$; xi 15 ; Heb. 111 .

s Burn Niceta p. clui.

VOL. VII.

G g 
$a$ is 'et ait Elisabet', in the Codex Veronensis, $b$ 'et ait Elisabel'. Bianchini's note in his edition of these versions': 'Porro Elisabeth dandi non nominandi casus est' cannot stand against the evidence of Niceta and Irenaeus.

The reading of Niceta seems to be supported by Cyril of Jerusalem. In his Catechetical Lectures he first speaks of the work of the Holy



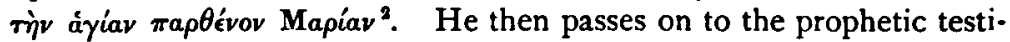
mony of the Holy Spirit in the persons of Elisabeth, Zacharias, and

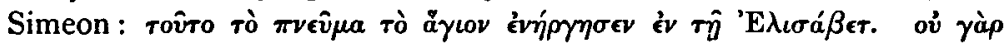



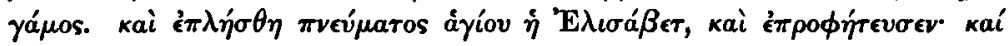



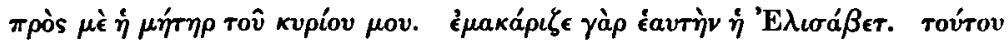

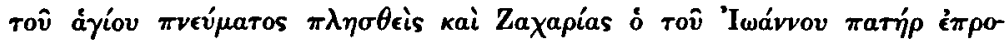

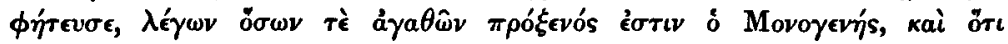

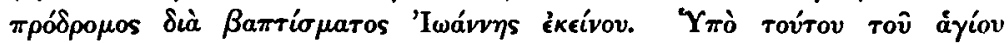

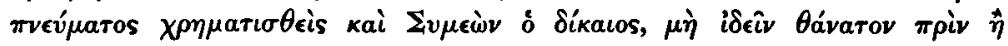

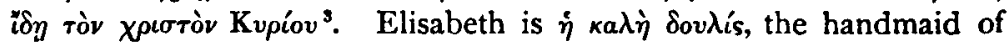
the Lord, the $\delta o v$ $\lambda \eta$ of the Magnificat (Lk. i 48 ), and thus distinct from

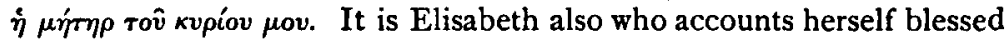
(Lk. i 48 ). The collocation of the phrases : $\dot{\pi} \pi \dot{\eta} \sigma \theta \eta \eta$

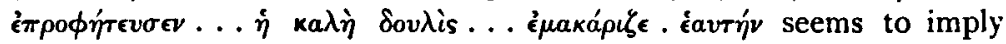
that the whole passage (Lk. i 42-56) including the Magnificat was understood by Cyril of Elisabeth. Cyril passes at once to the case



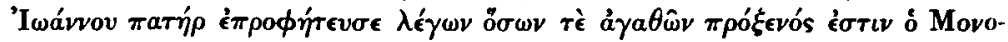


almost the very phrase in which St Luke introduces the Benedictus, and gives a summary of the Canticle. The words roútov . . . $\pi \lambda \eta \sigma \theta$ eis

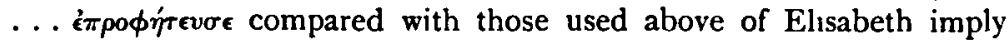
that in each case the Canticle is referred to as the illustration of the prophetic testımony of the Holy Spirit. Cyril then passes to the case

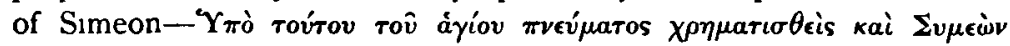

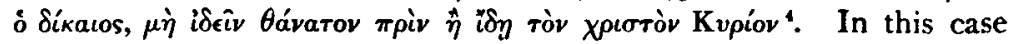
the Nunc Dimittis is not so clearly referred to, but the collocation of the three cases of Elisabeth, Zacharias, and Simeon implies that Cyril has in his mind the testimony of the Holy Spirit in the three Canticles, and that he attributes them severally to Elisabeth, Zacharias, and Simeon. He has St Luke before him and follows his order, and he does not speak of any prophetic utterance (i் $\pi$ o $\phi \dot{\eta} \tau \epsilon \boldsymbol{\sigma \epsilon})$ of Mary.

1 Bianchini Evang. Quad. vol. i, pt. 11, p. xiri.

ab. xvii 7 .
2 Cyr. Hier. Cat. xvii 6.

4b. xvii 7 . 
The passage is of importance in itself. Still more significant is Touttée's note in the Benedictine edition, shewing the attempts made to accommodate the original text to the later ascription of the Magnificat to the Blessed Virgin. The note is on the word eavrîs in the sentence

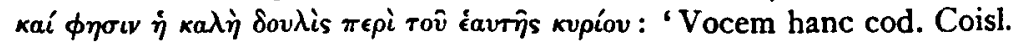

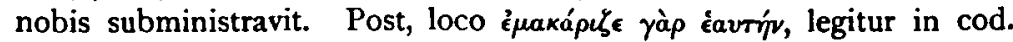

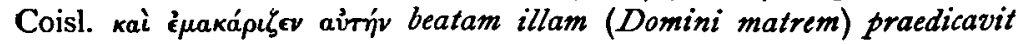
(Elizabetha) nempe his verbis Luc. i 45 iuxta Vulgatam: Beata es quae credidisti. Eodem modo legit Grodecius, nisi quod $\eta \dot{\lambda} \lambda \operatorname{có}_{\eta} \sigma \epsilon v$,

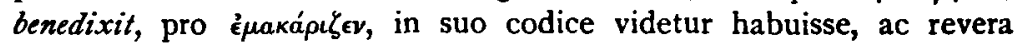
benedixit his verbis v. 42: Benedicta th in mulieribus etc. Cod.

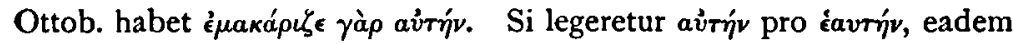
esset ac textus scripturae.' 1 Cod. Coisl. has evidently introduced the word $\dot{\epsilon} a v r \hat{\eta} s$, and altered the last sentence to av่rív, to give the words to the Blessed Virgin.

Niceta and Cyril agree in ascribing the Magnificat to Elisabeth. Niceta is not here dependent on Cyril, for in the words 'Cum Elisabeth Dominum anima nostra magnificat', he appears to speak as the representative of his own people, and to point to the common use of the Church.

Is there any traditional connexion between the Church of Jerusalem and the Latin Church of the Danube which will explain the affinity between the reading of Cyrl and the reading of Niceta? The traditions of Jerusalem scarcely go higher than the forty years' episcopate of Alexander of Cappadocia in the first half of the third century. There is no continuity in the earlier traditions. Alexander, the friend of Firmilian, the patron of Origen, was the reorganizer of the Church of Jerusalem. He brought with him his Creed, which was traceable in a MS seen by Victorinus of Pettau in the Library at Jerusalem". He was the founder of the Library. In matters of discipline he refers to the custom of the Churches of Asia. He was of such high standing in Cappadocia before he was called to the Church of Jerusalem, that in $21 \mathrm{I}$, on the death of Serapion of Antioch, he wrote and congratulated the Church of Antioch on the appointment of Asclepiades, and testified that the new bishop was qualified for the work in regard to the true faith. Alexander is an important link between the Church of Jerusalem and the Church of Cappadocia. And it was to Cappadocia that the Church of the Danube owed her earliest traditions. Captives from Cappadocia in the third century were among the first Christian missionaries on the Danube. Ulphilas was himself descended from one of these Cappadocian captives. The great road from East to West

1 Op. Cyr. Hier. ed. B \pm . ad loc.

2 Liber de Compute, Murat. Anecd. in p. 207.

G $\mathbf{g} 2$ 
through Bithynia and Thrace kept the Church of Dacia and Moesia and Illyricum in touch with the Church of Cappadocia. The correspondence of St Basil with Ascholius of Thessalonica and Valerianus of Aquileia is witness to the sympathy and intercourse between the two Churches.

Is it not possible that the common source of the reading 'Elisabeth' is to be traced to the Church of Cappadocia in the early years of the third century? May it not be that the reading belonged to a Codex of the 'Western' type in use in Cappadocia and Antioch, and that it is to such a Codex that Origen refers when he says 'Non enim ignoramus quod secundum alios codices et haec verba Elizabet vaticinatur' '. Between $23^{2}$ and 235 Origen visited Firmilian at Caesarea in Cappadocia, and according to Palladius he found refuge in the same city with Juliana during some period of persecution, which can only be the persecution of Maxıminus Thrax in 235-238. He had therefore ample opportunity during his visits to Cappadocia as well as in his intercourse with Alexander at Jerusalem of making himself acquainted with the reading 'Elisabeth'.

The influence of St Jerome once and for all disposed of the ascription of the Magnificat to Elisabeth. But how far is the interpretation of Is. viii 3 to be recognized as a determining factor in the Church of the fourth century? Jerome in his comment on the text of Isaiah 'et accessi ad prophetissam, et concepit et peperit filium' says 'Quidam prophetissam sanctam Mariam interpretantur, quam prophetam fuisse non dubium est. Ipsa enım loquitur in Evangelıo : Ecce enim amodo beatam me dicent omnes generationes : quonıam fecit mihi magna qui potens est'. The reference of St Jerome may be to the Commentary on Isaiah ascribed by Maran to St Basil, but held to be of doubtful authenticity by Bardenhewer. It is, however, a work of the period of the Anomoean controversy, between 360 and 370 . The commentator

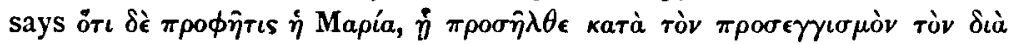

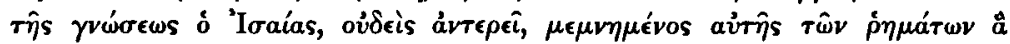

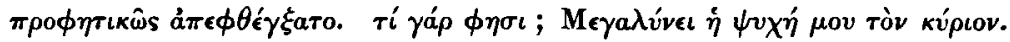

The prophecy of Elisabeth has been definitely set aside for the prophecy of Mary, and the words of Isaiah which follow 'et concepit et peperit' found their fulfilment in the Incarnation. If Maran be right, and the Commentary is to be ascribed to Basil, the reading 'Elısabeth' had disappeared or had been set aside in the Cappadocian codices of the fourth century.

The evidence on the whole points to the authority of the old Church of Cappadocia as the source of the Latin and the Jerusalem readings. Tertullian read 'Marıa': 'Exultat Elızabeth, Ioannes intus impulerat:

1 Or. Hom. vil in Luc. 
glorificat Dominum Maria, Christus intus instinxerat.' ${ }^{1}$ Origen read 'Maria': 'Ante Ioannem prophetat Elızabet, ante ortum Dominı Salva-

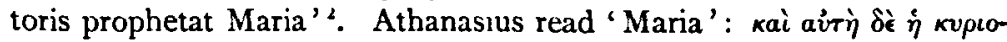

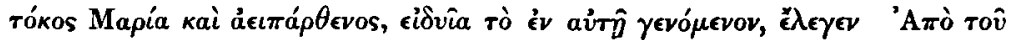

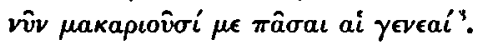

The African Latin text and the Alexandrine Greek seem to be united against the European Latin and the old Jerusalem text. Are not these independent evidences of the text before the Antiochene revision, a text either identical with or clearly allied to the 'Western' text, and to be sought for in the Churches of Cappadocia and Antioch in the third century? It was at this period that there is evidence of the closest intercourse between Cappadocia and Antioch and Jerusalem, witness to which is found not only in the authority of Alexander of Cappadocia, but in the position taken by Firmllian of Caesarea in the Synods of Antioch against Paul of Samosata. It is at this period that the old route to the West was superseded by the northern road from Cappadocia through Bithynia to the Danube Provinces and North Italy. It is along this line of road, and especially in the Latin Church of the Danube, that affinity may be traced between East and West, and that Greek rites, Greek traditions, Greek formularies are to be found in a Latin dress. The combined witness of Niceta and Cyril of Jerusalem thus opens up some interesting points as to the affinity of the 'European' Latin, and 'Western' Greek texts. Does it help towards the solution of the question of the future, Are the oldest forms of the old Latin and the old Syriac independent? And in view of the literary activity of the Latin Church of the Danube, as witnessed by the writings of Victorinus of Pettau and Niceta of Remesiana, not to mention the Greek and Latin treatises of Photinus of Sirmium, and the testimony of Jerome in his Epistle to Sunnia and Fretela, is it not to this Church that the origin of the European Latin is to be traced?

THOMAS BarNS.

[ $\mathrm{x}$. Cyril is lecturing, not on the canticles, but on the Holy Ghost, and accordingly quotes from the early chapters of the Gospels the passages in which the Holy Ghost is mentioned, viz. Lk. i 35, 4I, 67, i1 26 , i 15 ; Mt. iii I I ; Jn. i 33 , \&c, and there is no direct reference

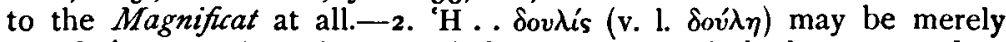
correlative to tov kvpiov $\mu$ ov of the words of Elizabeth as quoted.-

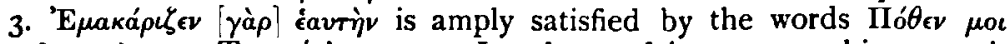

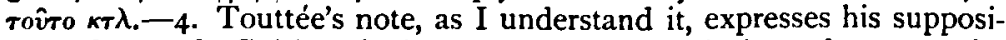
tion that cod. Coisl. substitutes aưrív for ćavrív in order to make

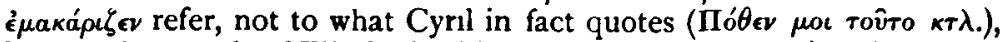

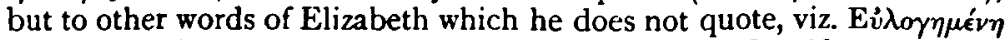

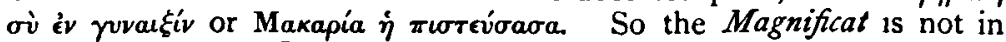
question.-F. E. B.]

1 Tert. de anima i 26.

s Ex. comm. S. Athan. in Luc.
2 Or. Hom. viii in Luc.

- Burkitt Encyc. Bibl. p. 4990. 